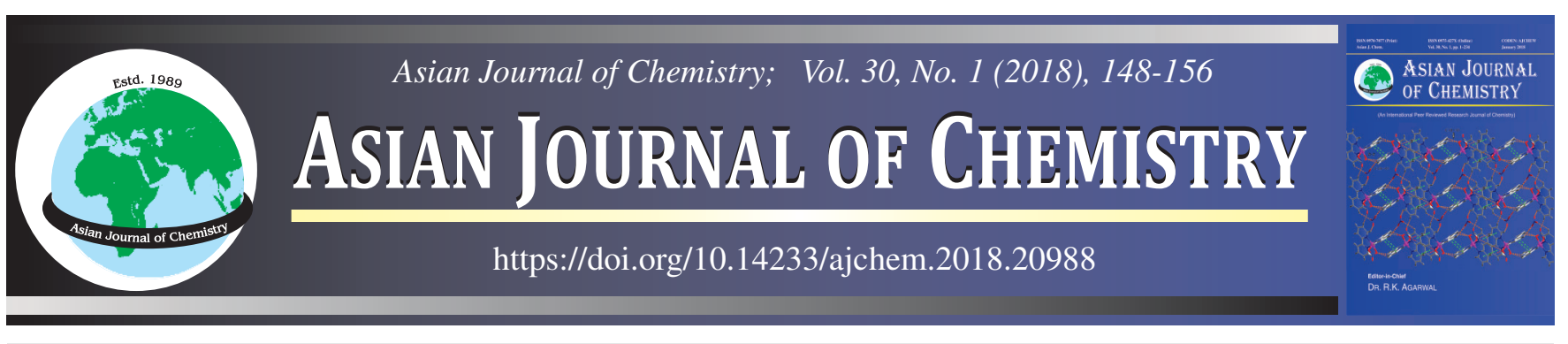

\title{
A QSAR Analysis of Flavone Derivatives of Antimalarial Compounds Based on PM3 Semi-Empirical Method
}

\author{
RUSLIN HADANU ${ }^{1,2, *}$
}

${ }^{1}$ Department of Chemistry Education, Faculty of Teacher Training and Education Science, Pattimura University, Ambon, Maluku 97234, Indonesia ${ }^{2}$ Sembilanbelas November Kolaka University, Kolaka-Sulawesi Tenggara 93517, Indonesia

*Corresponding author: Tel: + 6852 28447288; E-mail: ruslinhadanu@ gmail.com

\begin{abstract}
The study of flavone as antimalarial compounds have been carried out by as reported earlier, but studies of QSAR for modeling flavone derivatives as new drugs to replace antimalarials that have been resistant not been carried out. The descriptors of QSAR were calculated using PM3 semi-empirical method. The best model of QSAR was determined by MLR approach. Based on the best equation of QSAR models have been designed several new antimalarial compounds that are predicted to have a higher antimalarial activity than the flavone compounds. The best equation of QSAR models have been designed for 39 compounds of flavone derivatives and only 28 compounds of flavone derivatives that can be recommended to be synthesized or isolated from natural materials in the laboratory, i.e. 17-29, 32-33, 35 and 40-51 who have $\mathrm{IC}_{50}$ values as much as 1.151-1.751 $\mu \mathrm{M}$.

Keywords: Flavone, QSAR, Antimalarial, PM3, MLR.
\end{abstract}

\section{INTRODUCTION}

Malaria is a serious infectious disease that affects people of all ages, particularly in tropical and subtropical regions of the world. According to the World Health Organization [1], about half of the world's population is at risk of malaria and over two million annual deaths (mostly among African children) can be attributed to malaria alone and 1.5-2.7 million deaths per year globally [1,2]. Currently, $40 \%$ of the world's population is at risk of malaria. Every 30 seconds, a child dies from malaria. Those children who survive often are inflicted with brain damage and learning impairments [2]. In Indonesia, according to the results of household health survey (HHS) in 2001, there were 70 million people living in malaria endemic areas and 56.3 million people are living in malaria endemic areas of moderate to high. Although the incidence of malaria since 2000 tended to decrease, it still happens extraordinary events (outbreak) in 7 provincial malaria that attacked 35 villages and causing the death of 211 people [3]. In many parts of the world the parasites have developed resistance to a number of antimalarials such as chloroquine and halofantrine derivatives, the most widely used treatment for malaria and so there is an urgent need to discover new compounds as antimalarial drugs [4]. The P. falciparum, the protozoan agent responsible for cerebral malaria, is the most worrying parasite, in particular with chloroquine and multi-resistant strains. Besides the worldwide development of chloroquine-resistant $P$. falciparum resistance has also evolved to a variety of quinoline analogs, antifolates, inhibitors of electron transport and perhaps now to artemisinine $[5,6]$.

Multi drug-resistant of $P$. falciparum strains are an increasing problem in endemic areas and there are partly responsible for the worsening malaria situation around the world. A new active compound in combination with drugs that are available in the field is needed. The aim of this work was to explore the potential antiplasmodial effect of avone derivatives on parasites growth in vitro. The not only strain of $P$. falciparum, but also the strains of $P$. yoelii have been reported to have resistance to the antimalarial drug of artemisinine [7].

There are major factors as barriers in efforts to combat malaria. One of the major factors as obstacles in the fight against malaria is the emergence of malaria vectors to insecticides and parasite resistance to antimalarial available, particularly antimalarial chloroquine as the main option. Another factor that complicates chemotherapy of modern malaria is a strain of plasmodium (especially $P$. falciparum) resistant to antimalarials has been reported in some developing countries and developed countries e.g. P. falciparum and P. vivax resistant to antimalarial chloroquine [8]. This resistance problem has become a serious and dangerous problem since led to numerous failures in the treatment of even cause death. This prompted the researchers tried to find new antimalarial to replace anti- 
malarial that is not sensitive anymore. Without new antimalarial is expected to become a refractory disease in the coming decades.

Many efforts have been taken by researchers is to find of new antimalarial among others through the isolation of active compounds from natural ingredients traditionally used to treat malaria and through the synthesis of compounds that have been known to have antimalarial activity e.g., group quinoline, 4-aminoquinoline, 8-aminoquinoline, phenanthrene derivatives and phenanthroline derivatives. From phenanthrene has successfully developed the new antimalarial activity halofantrine better than chloroquine. However, halofantrine proved to have shortcomings that bioavailability varying side effects on the heart are dangerous, as well as some of the results of previous studies, have shown the occurrence of resistance of plasmodium to halofantrine [9].

The research on flavone derivatives as antimalarial compounds have been carried out by previous researchers, among others 1,10-phenanthroline derivatives [9], dehydrosilybine and 8-(1,1)-DMA-kaempferide compounds have $\mathrm{IC}_{50}$ values from 1.7 to $23.9 \mu \mathrm{M}$ and 2.1 to $10.1 \mu \mathrm{M}$, respectively [10]. However, the value of the activity of both flavone compounds is still below the antimalarial drug activity that has been circulating in the market such as chloroquine and halofantrine. However, the activity of the flavone both values are still below the antimalarial drug activity that has been circulating in the market such as chloroquine and halofantrine. A few years ago has been tested against the antimalarial activity of 16 compounds of flavone derivatives, but the value of antimalarial activity was still lower than antimalarials of chloroquine and halofantrine [11]. In vitro antiplasmodial activity of flavone has been evaluated by $P$. falciparum $\mathrm{W} 2$ strains $[10,11]$. The study of flavone as antimalarial compounds have been carried out by previous researchers, but studies of quantitative structure and activity relationship (QSAR) for modeling flavone derivative compounds as new drugs to replace antimalarials that have been resistant not been carried out. To obtain the derivatives of the flavone that have a higher antimalarial activity, it is necessary a molecular modeling method through the study of QSAR. QSAR studies is a very precise method because in addition to obtain a compound having high activity theoretically, also to shorten the time and reduce costs for drug development. In this research, QSAR analysis plays an important role to minimize trial and error in designing new antimalarial drugs.

In a QSAR analysis, the central task is to find a regression function that predicts the activity of the molecule in high accuracy. Hence, the present study is aimed to establish the QSAR between experimental antiplasmodial activity and structure electronic or descriptors, which may focus on the molecular structures of the compounds. In last decades, QSAR has been applied in many areas enabling to prevent time consuming and cost during the analysis of biological activities of interest [12]. The main hypothesis involved in any QSAR is the assumption that the variation of the behaviour of chemical compounds, as expressed by any experimentally measured biological property, can be correlated with numerical entities related to some aspect of the chemical structure termed molecular descriptors $[12,13]$. The descriptors are generally used to describe different characteristics of the chemical structure in order to yield information about the activity being studied. In general, QSAR studies are effected by various factors from which the most relevant are: (a) the selection of the best molecular descriptors that should include maximum information of molecular structures and a minimum overlap between them; (b) to optimize the a number of descriptors to be included in the best equation of QSAR model; (c) the use of suitable modeling methods; (d) determining the value of the activity $\left(\mathrm{IC}_{50}\right)$ using descriptors optimized and using the best equation of QSAR model and (e) the employment of validation techniques to verify the predictive performance of the developed models.

In this study used statistical analysis of multilinear regression method. Multilinear Regression method is a statistical technique to analyze the dataset of the series flavone derivative compounds, such as some of the development of the equation QSAR models to predict the theoretical $\mathrm{IC}_{50}$ value of a drug compound based on the $\mathrm{IC}_{50}$ value of experimental results is known. In this way, we resort to the replacement method (RM) as a variable selection approach was applied to the pond section that contains more than a thousand descriptors because this technique has managed to select the relevant structural descriptors [14-17]. Finally, another main interest of present research is to apply the so derived QSAR models for estimating the antiplasmodial potency on some new structures, for which there still are no experimental activities.

In this research PM3 semi-empirical methods were used to calculate a number of descriptors. The PM3 semi-empirical method was used to calculate a number of descriptors because the structure of flavone derivatives having bulky structures and two atoms oxygen. In the research developed at this time, PM3 semi-empirical method serves as a highly efficient computational tool that can produce a quantitative estimate of the number of descriptors. This may be particularly useful for correlating large sets of experimental and theoretical data, for establishing trends in classes of related molecules and for scanning a computational problem before proceeding with higher level treatments. Among the classes of drugs that are effective in the treatment of the $P$. falciparum, there is the flavone and its derivatives. The flavone derivative compounds were synthesized from flavone as a starting material. The best equation of QSAR model was modeled, described and evaluated for their antiplasmodial activity. From that evaluation, the flavone appeared as a new class of potential antiplasmodial compounds [18]. The cyclic ring system of flavone derivatives compounds with multiple applications which have been the subject of great interest because of their biological activities. The four substituents (R4, R6, R7 and R4') of flavone derivatives (Table-1) has emerged in its usage as a core structure in the diversified therapeutically applications $[11,12]$. Previous QSAR analysis has been reported using electronic descriptor producing by PM3 calculation using 16 flavone series compound.

\section{EXPERIMENTAL}

The flavone derivatives compounds were taken from literature [11]. Inhibition concentration $\left(\mathrm{IC}_{50}\right)$ was used as dependent variable in this QSAR study (Table-1). 
In this research, a Laptop equipped with Intel ${ }^{\circledR}$ Dual Core Processor 2.20 GHz; RAM 894 MB and HDD 250 GB was used. All the compounds (Table-1) were calculated using package HyperChem ${ }^{\circledR}$ Program Version 8.0 for Windows and complete geometry optimization with the semi-empirical PM3 method, algorithm Polak-Ribiere, RMS gradient of $0.001 \mathrm{kcal} /(\AA \mathrm{mol})$ and using statistical program IBM ${ }^{\circledR}$ SPSS $^{\circledR}$ version 16 for windows.

Computational methods: The QSAR models are evaluated using sets of flavone derivatives compounds. The QSAR descriptors were calculated for each of the compounds in Table-1. All the compounds were calculated using package HyperChem ${ }^{\circledR}$ Program Version 8.0 for Windows and complete geometry optimization with the semi-empirical PM3 method was performed. The molecule structure was optimized to a Root Mean Square (RMS) gradient of $0.001 \mathrm{kcal} /(\AA \mathrm{mol})$ in vacuo (PolakRibière method). The value of the antiplasmodial activity of these compound was taken as the activity against chloroquineresistant $P$. falciparum $\mathrm{W} 2$ strain and is presented as the value of $1 / \log \mathrm{IC}_{50}$ where $\mathrm{IC}_{50}$ is an effective concentration inhibiting $50 \%$ growth of the parasite [11]. The full list of descriptors considered is reported in Table-2. The value of the antiplasmodial activity of these compound was taken as the activity against chloroquine-resistant $P$. falciparum $\mathrm{W} 2$ strain and is presented as the value of $\log \mathrm{IC}_{50}$ where $\mathrm{IC}_{50}$ is an effective concentration inhibiting $50 \%$ growth of the parasite [11]. The quantum chemical descriptors were calculated, as for example: atomic net charges, dipole moment, $\mathrm{E}_{\text {номо, }} \mathrm{E}_{\mathrm{Lumo}}$ and $\log$ P. From all the descriptors above mentioned, it can be considered that some of them give valuable information about the influence of electronic and coefficient partition features upon the biological activity of drug molecules. In this research, the molecular descriptors were selected so that they represent the features necessary to quantify the theoretical of antimalarial activity ( $\mathrm{IC}_{50}$ calculated).

Evaluation of QSAR models: The structure of synthesized flavone derivatives was optimized with the semi-empirical method PM3 (Parametric Method-3) using package HyperChem ${ }^{\circledR}$ Program Version 8.0 for Windows. We choose a gradient norm limit of $0.001 \mathrm{kcal} / \AA$ for the geometry optimization. Further, the regression analysis was performed using SPSS 16 for Windows to get the equation of QSAR model. The finally step is to design the new compound of flavone derivatives according to the best equation of QSAR model and consider of eligibility of synthesis and the making of flavone derivatives resulted from molecular design which has the highest predicted value of $\mathrm{IC}_{50}$ to be synthesized in the laboratory. The net charge atoms for three dimension of molecule structure which have experienced converged at the process of optimization can be recorded through menu file; start log; compute; single point and then stop log. The net charge of atoms on its structural compound can be seemed through display menu, label and charge.

\section{RESULTS AND DISCUSSION}

A QSAR study is an analysis of quantitative structure and activity relationship as interest for the development of new drugs to determine theoretically of drug activity. In addition to the QSAR analysis is also intended to minimize the costs and to limit the time required for the development of a new drug. The development of drugs in this research is based on research conducted by Rodrigues et al. [11] to 16 flavone derivative compounds (Table-1) using the standard chloroquine compound as an antimalarial which has been circulating in the market. But unfortunately, the value of antimalarial activity

TABLE-1

CHEMICAL STRUCTURE AND ACTIVITY DATA OF ANTIMALARIAL COMPOUNDS OF FLAVONE DERIVATIVES AGAINST $P$. falciparum W2 STRAIN, OBTAINED FROM RODRIGUES [Ref. 1]<smiles>[R]c1ccc(-c2oc3cc([R])c([R])c(=O)c-3cc2[R])cc1</smiles>

\begin{tabular}{|c|c|c|c|c|c|c|}
\hline No. & $\mathrm{R}^{3}$ & $\mathrm{R}^{6}$ & $\mathrm{R}^{7}$ & $\mathrm{R}^{4^{\prime}}$ & $\mathrm{IC}_{50} \mu \mathrm{M}$ & $1 / \log \mathrm{IC}_{50}$ \\
\hline 1 & $\mathrm{H}$ & $\mathrm{H}$ & $\mathrm{OC}_{6} \mathrm{H}_{4}-4-\mathrm{Cl}$ & $\mathrm{H}$ & 21.00 & 0.76 \\
\hline 2 & $\mathrm{H}$ & $\mathrm{Cl}$ & $\mathrm{OC}_{6} \mathrm{H}_{4}-4-\mathrm{Cl}$ & $\mathrm{H}$ & 25.00 & 0.72 \\
\hline 3 & $\mathrm{Cl}$ & $\mathrm{H}$ & $\mathrm{OC}_{6} \mathrm{H}_{4}-4-\mathrm{Cl}$ & $\mathrm{H}$ & 12.60 & 0.91 \\
\hline 4 & $\mathrm{CH}_{3}$ & $\mathrm{H}$ & $\mathrm{OC}_{6} \mathrm{H}_{4}-4-\mathrm{Cl}$ & $\mathrm{H}$ & 19.70 & 0.91 \\
\hline 5 & $\mathrm{CH}_{3}$ & $\mathrm{Cl}$ & $\mathrm{OC}_{6} \mathrm{H}_{4}-4-\mathrm{Cl}$ & $\mathrm{H}$ & 23.20 & 0.74 \\
\hline 6 & $\mathrm{CH}_{3}$ & $\mathrm{Cl}$ & $\mathrm{OC}_{6} \mathrm{H}_{4}-4-\mathrm{OCF}_{3}$ & $\mathrm{H}$ & 25.00 & 0.72 \\
\hline 7 & $\mathrm{H}$ & $\mathrm{H}$ & $\mathrm{OC}_{6} \mathrm{H}_{4}-3-\mathrm{OCF}_{3}$ & $\mathrm{H}$ & 14.90 & 0.85 \\
\hline 8 & $\mathrm{CH}_{3}$ & $\mathrm{Cl}$ & $\mathrm{O}\left(\mathrm{CH}_{2}\right)_{3} \mathrm{CF}_{3}$ & $\mathrm{H}$ & 17.20 & 0.81 \\
\hline 9 & $\mathrm{CH}_{3}$ & $\mathrm{Cl}$ & $\mathrm{Ph}$ & $\mathrm{H}$ & 14.00 & 0.87 \\
\hline 10 & $\mathrm{H}$ & $\mathrm{H}$ & $\mathrm{Br}$ & $\mathrm{H}$ & 25.00 & 0.72 \\
\hline 11 & $\mathrm{CH}_{2} \mathrm{Br}$ & $\mathrm{Cl}$ & $\mathrm{Ph}$ & $\mathrm{Br}$ & 5.96 & 1.30 \\
\hline 12 & $\mathrm{CH}_{3}$ & $\mathrm{Cl}$ & $\mathrm{Ph}$ & $\mathrm{Br}$ & 25.00 & 0.72 \\
\hline 13 & $\mathrm{H}^{3}$ & $\mathrm{H}$ & $\mathrm{Ph}$ & $\mathrm{H}$ & 25.00 & 0.72 \\
\hline 14 & $\mathrm{H}$ & $\mathrm{H}$ & $\mathrm{C}_{6} \mathrm{H}_{4}-\mathrm{Cl}$ & $\mathrm{H}$ & 10.00 & 1.00 \\
\hline 15 & $\mathrm{H}$ & $\mathrm{H}$ & $\mathrm{C}_{6} \mathrm{H}_{4}-\mathrm{F}$ & $\mathrm{H}$ & 25.00 & 0.72 \\
\hline 16 & $\mathrm{H}$ & $\mathrm{H}$ & $\mathrm{C}_{6} \mathrm{H}_{4}-\mathrm{CHO}$ & $\mathrm{H}$ & 25.00 & 0.72 \\
\hline \multicolumn{5}{|c|}{ Chloroquine as standard } & 0.186 & \\
\hline
\end{tabular}


$\left(\mathrm{IC}_{50}\right)$ of flavone derivative compounds is still not equivalent to chloroquine antimalarial activity. Based on the foregoing, it is necessary to conduct further research on QSAR studies on antimalarial compound flavone derivative to obtain the best equation of QSAR model. Furthermore, the best equation of the QSAR model was used to predict new compounds of flavone derivative that has a high-value antimalarial activity. The best equation of QSAR model is highly effective in describing the structural basis of biological activity [19].

The descriptors are parameters or properties of the molecular structure obtained from the optimization of a series of flavone compounds that are known activities using HyperChem ${ }^{\circledR}$ Program Version 8.0 for Windows and used as independent variables in this study for the theoretical calculation of $\mathrm{IC}_{50}$ values. Process optimization is performed to obtain the structural properties of each test compound as well as a model compound and continued with the process of recording data through a single point menu. The descriptors used in this research are atomic net charges, dipole moment, $\mathrm{E}_{\text {Hомо }}, \mathrm{E}_{\mathrm{Lumo}}$ and $\log \mathrm{P}$.

In this study, a number of flavone derivative compounds are designed to find new molecules of flavone have high antimalarial activity theoretically. There are some flavones as an antimalarial compound has already been studied by researchers, but the results are not satisfactory. The new molecular design effort is done through an analysis of QSAR to 16 flavone derivatives that are known for their activity using laboratory experiments [11]. The method of calculation to obtain the descriptors used in this study in accordance with the calculation method descriptor that is used by Motta et al. [20] in a QSAR analysis of the chalcone derivative series as antimalarial compounds. The descriptors used in this research are atomic net charges, dipole moment, $\log$ P, $\mathrm{E}_{\text {номо, }} \mathrm{E}_{\mathrm{Lumo}}$ and $\log \mathrm{P}$. To obtain the structural properties of each test compound and modeling compound after a process of geometry optimization, the calculation process is continued with a single point at sub menu.

Optimation of flavone derivatives compounds: In the design of molecules through QSAR analysis is highly dependent on the descriptors used in the optimization process to a series of flavone compounds with known activities. The descriptors yielded from the calculation with the single point where atomic net charges and dipole moment, whereas the description of $\log$ P, were obtained from "menu compute" of QSAR properties. $\mathrm{E}_{\text {номо, }} \mathrm{E}_{\mathrm{Lumo}}$ descriptors can be obtained from the menu compute, vibrations then click orbital sub menu. To calculate of atomic net charges and other descriptors of a

\begin{tabular}{|c|c|c|c|c|c|c|c|c|c|c|}
\hline \multicolumn{11}{|c|}{$\begin{array}{c}\text { TABLE-2 } \\
\text { DESCRIPTORS/INDEPENDENT VARIABLES USED FOR QSAR ANALYSIS OF } \\
\text { ANTIMALARIAL COMPOUNDS OF FLAVONE DERIVATIVES }{ }^{\mathrm{a}}\end{array}$} \\
\hline No. & $\mathrm{qO} 1$ & $\mathrm{qC} 2$ & $\mathrm{qS} 3$ & $\mathrm{qC} 4$ & $\mathrm{qC5}$ & qC6 & $\mathrm{qC7}$ & $\mathrm{qC} 8$ & qC9 & $\mathrm{qC} 10$ \\
\hline 1 & -0.105 & 0.157 & -0.313 & 0.384 & -0.007 & -0.144 & -0.044 & -0.147 & -0.211 & 0.108 \\
\hline 2 & -0.103 & 0.159 & -0.312 & 0.383 & -0.010 & -0.170 & -0.048 & -0.134 & -0.200 & 0.107 \\
\hline 3 & -0.103 & 0.158 & -0.311 & 0.384 & 0.006 & -0.147 & -0.075 & -0.153 & -0.215 & 0.122 \\
\hline 4 & -0.105 & 0.156 & -0.312 & 0.385 & -0.003 & -0.148 & -0.014 & -0.152 & -0.219 & 0.114 \\
\hline 5 & -0.104 & 0.158 & -0.311 & 0.384 & -0.005 & -0.174 & -0.011 & -0.141 & -0.208 & 0.113 \\
\hline 6 & -0.104 & 0.156 & -0.310 & 0.384 & -0.005 & -0.174 & -0.011 & -0.141 & -0.208 & 0.112 \\
\hline 7 & -0.104 & 0.157 & -0.312 & 0.384 & -0.008 & -0.144 & -0.044 & -0.147 & -0.211 & 0.108 \\
\hline 8 & -0.105 & 0.164 & -0.317 & 0.385 & -0.005 & -0.174 & -0.012 & -0.142 & -0.208 & 0.113 \\
\hline 9 & -0.103 & 0.158 & -0.312 & 0.384 & -0.005 & -0.174 & -0.012 & -0.142 & -0.208 & 0.113 \\
\hline 10 & -0.104 & 0.150 & -0.306 & 0.383 & -0.007 & -0.143 & -0.043 & -0.147 & -0.212 & 0.108 \\
\hline 11 & -0.093 & 0.190 & -0.343 & 0.389 & -0.015 & -0.148 & -0.054 & -0.108 & -0.183 & 0.098 \\
\hline 12 & -0.095 & 0.187 & -0.341 & 0.392 & -0.007 & -0.172 & -0.012 & -0.137 & -0.202 & 0.105 \\
\hline 13 & -0.104 & 0.158 & -0.314 & 0.384 & -0.008 & -0.144 & -0.044 & -0.148 & -0.212 & 0.108 \\
\hline 14 & -0.104 & 0.156 & -0.312 & 0.384 & -0.008 & -0.144 & -0.044 & -0.147 & -0.211 & 0.108 \\
\hline 15 & -0.104 & 0.155 & -0.311 & 0.384 & -0.007 & -0.144 & -0.044 & -0.147 & -0.212 & 0.108 \\
\hline 16 & -0.103 & 0.154 & -0.310 & 0.383 & -0.007 & -0.144 & -0.044 & -0.147 & -0.212 & 0.108 \\
\hline No. & $\mathrm{qC1}$ & $\mathrm{qC} 2$ & $\mathrm{qC} 3$ & $\mathrm{qC} 4$ & $\mathrm{qC} 5$ & qC6' & $\begin{array}{c}\mu \\
\text { (Debyes) }\end{array}$ & $\begin{array}{c}\mathrm{E}_{\mathrm{LUMO}} \\
(\mathrm{ev})\end{array}$ & $\begin{array}{c}\mathrm{E}_{\mathrm{HOMO}} \\
(\mathrm{ev})\end{array}$ & $\log \mathrm{P}$ \\
\hline 1 & -0.086 & -0.039 & -0.153 & 0.086 & -0.121 & -0.062 & 3.172 & -1.011 & -9.289 & 0.26 \\
\hline 2 & -0.088 & -0.038 & -0.155 & 0.088 & -0.121 & -0.060 & 3.476 & -1.096 & -9.249 & 0.04 \\
\hline 3 & -0.088 & -0.038 & -0.154 & 0.088 & -0.121 & -0.061 & 2.699 & -1.097 & -9.362 & 0.04 \\
\hline 4 & -0.085 & -0.040 & -0.153 & 0.085 & -0.121 & -0.062 & 3.423 & -0.985 & -9.263 & 0.42 \\
\hline 5 & -0.087 & -0.039 & -0.154 & 0.087 & -0.121 & -0.061 & 3.646 & -1.066 & -9.209 & 0.19 \\
\hline 6 & -0.085 & -0.039 & -0.152 & 0.083 & -0.119 & -0.061 & 2.622 & -1.113 & -9.244 & 1.36 \\
\hline 7 & -0.091 & -0.033 & -0.161 & 0.082 & -0.125 & -0.056 & 3.535 & -1.044 & -9.243 & 1.43 \\
\hline 8 & -0.112 & -0.019 & -0.195 & 0.116 & -0.144 & -0.043 & 4.547 & -1.000 & -9.158 & 1.39 \\
\hline 9 & -0.076 & -0.056 & -0.113 & -0.002 & -0.107 & -0.074 & 4.292 & -1.146 & -9.006 & 1.53 \\
\hline 10 & -0.064 & -0.057 & -0.089 & -0.098 & -0.083 & -0.076 & 2.857 & -1.008 & -9.405 & 1.04 \\
\hline 11 & -0.085 & -0.051 & -0.113 & 0.002 & -0.109 & -0.059 & 4.215 & -1.319 & -9.151 & 1.91 \\
\hline 12 & -0.083 & -0.052 & -0.113 & 0.001 & -0.109 & -0.059 & 4.419 & -1.049 & -9.104 & 1.70 \\
\hline 13 & -0.075 & -0.056 & -0.113 & -0.003 & -0.107 & -0.074 & 3.640 & -1.100 & -8.982 & 1.60 \\
\hline 14 & -0.072 & -0.057 & -0.111 & -0.007 & -0.105 & -0.075 & 3.048 & -1.203 & -8.956 & 1.37 \\
\hline 15 & -0.072 & -0.056 & -0.111 & -0.006 & -0.106 & -0.074 & 2.818 & -1.230 & -9.069 & 0.99 \\
\hline 16 & -0.067 & -0.058 & -0.105 & -0.018 & -0.100 & -0.077 & 1.102 & -1.362 & -9.170 & 0.57 \\
\hline
\end{tabular}

${ }^{\mathrm{a}}$ Descriptors were calculated using semi-empirical PM3 method. 
series of flavone derivatives was conducted with the semiempiric PM3 method. The PM3 method can be used for the analysis of flavone derivatives series, because the flavone derivatives series are organic molecules considering atoms as $\mathrm{C}, \mathrm{H}$ and two oxygen atoms. Then all of the descriptors were given in Table-2.

Selection of the best equation of QSAR model: The best equation of the QSAR model was obtained through statistical analysis through RML method using SPSS ${ }^{\circledR}$ Program Version 16 for Windows. Furthermore, the development stage of the selection of the best equation of a QSAR model derived from the results of the statistical analysis. Through statistical analysis acquired 12 equations of QSAR model shown in Table-4. Based on various criteria and standards in determining the best equation of QSAR model, it can be determined that the eqn. 1 of QSAR model as the best equation of QSAR model in this research. The eqn. 1 of QSAR model is selected as the best equation of QSAR model among 12 equations of QSAR models, based on the value of $r$ and $r^{2}$ to look for analysis data linearity that the eqn. 1 of QSAR model having $r$ equal to 1 is 0.950 and $r^{2}$ are 0.902 . The smallest value of SE (Standard Error of Estimation) is eqn. 1 of QSAR model having a value of $\mathrm{SE}$ equal to 0.188 . If the value of $\mathrm{F}_{\text {calculated }}$ is more than the value of $F_{\text {table }}$ or comparison of $F_{\text {calculated }} / F_{\text {table }}$ more than 1 or the eqn. 1 of QSAR model have the largest of $F_{\text {calculated }} / F_{\text {table }}$ value, then the eqn. 1 of QSAR model as the best equation of QSAR model, if compared with the equations of QSAR model that other. The eqn. 1 of QSAR model have a value of $\mathrm{F}_{\text {calculated }} / \mathrm{F}_{\text {table }}$ is 2.686. The eqn. 1 of QSAR model has a smaller value of the PRESS (0.03600) than another equation of QSAR model (Table-3). The statistical of the criteria above strongly supports the establishment of eqn. 1 as the best equation of QSAR model.

Every value of PRESS of each equation of QSAR model shows the difference of squares of $\mathrm{IC}_{50}$ from the results of laboratory experiments with values of $\mathrm{IC}_{50}$ theoretical. So the values of the smallest PRESS demonstrate the accuracy of the equation of QSAR model. Similarly, the criteria of statistical such as the value of $r, r^{2}$, SE value and the comparison value

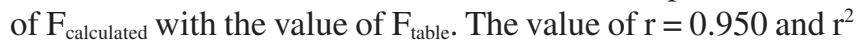
$=0.902$ to indicate that the correlation between electronic structure (independent variables) with the antimalarial activity very firm. This means that changes of antimalarial activity $\left(\mathrm{IC}_{50}\right)$ of the compound series flavone derivatives significantly due to the $95.0 \%$ of the change descriptors: electronic structure, dipole moment, $\mathrm{E}_{\text {Luмо, }} \mathrm{E}_{\text {номо }}$ and $\log \mathrm{P}$. Comparing parameters $\mathrm{F}$ and SE of the eleven equation of QSAR models, it is easy revealed that eqn. 1 of QSAR model is the best equation of QSAR model because its highest F and lowest SE value. According to the F, the value indicated that eqn. 1 of QSAR model is the significance at trust level $95 \%$ as shown by the ratio of $F_{\text {calculated }} / F_{\text {table }}$ which the value more than 1 . The value of $\mathrm{F}_{\text {calculated }}$ larger than $\mathrm{F}_{\text {table }}$ to indicated that $\mathrm{H}_{1}$ accepted and its showing correlate electronic structure (dependent variables) a series flavone derivatives between the activity of antimalarial

TABLE-3

TWELVE SELECTED QSAR MODELS AND THEIR STATISTICAL PARAMETERS FOR THE CORRELATION BETWEEN MOLECULAR PROPERTIES AND ANTIMALARIAL ACTIVITY OF FLAVONE DERIVATIVES ${ }^{\mathrm{a}}$

\begin{tabular}{|c|c|c|c|c|c|c|}
\hline $\begin{array}{l}\text { QSAR } \\
\text { models }\end{array}$ & Variables & $\mathrm{R}$ & $\mathrm{R}^{2}$ & SE & $\mathrm{F}_{\text {calc }} / \mathrm{F}_{\text {table (0.05) }}$ & PRESS \\
\hline 1 & qO1, qC4,qC5, qC6, qC7, qC8, qC9, qC1', q4', qC6', $\mu, \mathrm{E}_{\mathrm{Lumo}}, \mathrm{E}_{\mathrm{Hомо}}, \log \mathrm{P}$ & 0.950 & 0.902 & 0.18836 & 2.686 & 0.03600 \\
\hline 2 & $\mathrm{qO} 1, \mathrm{qC} 4, \mathrm{qC} 5, \mathrm{qC} 6, \mathrm{qC} 7, \mathrm{qC} 8, \mathrm{qC} 9, \mathrm{q}^{\prime}, \mathrm{qC} 6, \mu, \mathrm{E}_{\mathrm{Luмо}}, \mathrm{E}_{\text {номо }}, \log \mathrm{P}$ & 0.950 & 0.902 & 0.13322 & 0.073 & 0.03603 \\
\hline 3 & qO1, qC4,qC5, qC6, qC7, qC8, qC9, q4', qC6', $\mathrm{E}_{\mathrm{LuMO}}, \mathrm{E}_{\mathrm{Hомо}}, \log \mathrm{P}$ & 0.949 & 0.901 & 0.10911 & 0.261 & 0.03659 \\
\hline 4 & $\mathrm{qO} 1, \mathrm{qC} 4, \mathrm{qC} 5, \mathrm{qC} 6, \mathrm{qC} 7, \mathrm{qC} 8, \mathrm{q}^{\prime}, \mathrm{qC} 6^{\prime}, \mathrm{E}_{\mathrm{LUMO}}, \mathrm{E}_{\text {номо }}, \log \mathrm{P}$ & 0.948 & 0.899 & 0.09574 & 0.545 & 0.03744 \\
\hline 5 & $\mathrm{qO} 1, \mathrm{qC} 4, \mathrm{qC} 5, \mathrm{qC} 6, \mathrm{qC} 7, \mathrm{qC} 8, \mathrm{qC} 6, \mathrm{E}_{\text {LUмо }}, \mathrm{E}_{\text {номо }}, \log \mathrm{P}$ & 0.945 & 0.893 & 0.08812 & 0.878 & 0.03975 \\
\hline 6 & qO1, qC4,qC5, qC6, qC7, qC8, qC6', $\mathrm{E}_{\mathrm{LuMO}}, \mathrm{E}_{\text {номо }}$ & 0.934 & 0.872 & 0.08792 & 1.107 & 0.04684 \\
\hline 7 & $\mathrm{qC} 4, \mathrm{qC} 5, \mathrm{qC} 6, \mathrm{qC} 7, \mathrm{qC} 8, \mathrm{qC} 6, \mathrm{E}_{\mathrm{Luмо}}, \mathrm{E}_{\text {номо }}$ & 0.928 & 0.861 & 0.08485 & 1.451 & 0.05123 \\
\hline 8 & qC4, qC5, qC6, qC7, qC8, qC6', Е Еомо & 0.922 & 0.850 & 0.08250 & 1.845 & 0.05542 \\
\hline 9 & $\mathrm{qC} 4, \mathrm{qC} 5, \mathrm{qC} 6, \mathrm{qC} 7, \mathrm{qC} 8, \mathrm{E}_{\text {номо }}$ & 0.901 & 0.812 & 0.08697 & 1.923 & 0.06981 \\
\hline 10 & $\mathrm{qC} 5, \mathrm{qC} 6, \mathrm{qC} 7, \mathrm{qC} 8, \mathrm{E}_{\text {номо }}$ & 0.875 & 0.766 & 0.09205 & 1.967 & 0.08638 \\
\hline 11 & $\mathrm{qC} 5, \mathrm{qC} 6, \mathrm{qC} 8, \mathrm{E}_{\text {номо }}$ & 0.847 & 0.717 & 0.09660 & 2.069 & 0.10434 \\
\hline 12 & $\mathrm{qC} 5, \mathrm{qC} 6, \mathrm{qC} 8$ & 0.806 & 0.650 & 0.10285 & 2.124 & 0.12844 \\
\hline
\end{tabular}

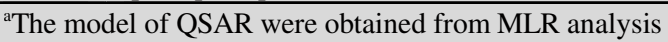

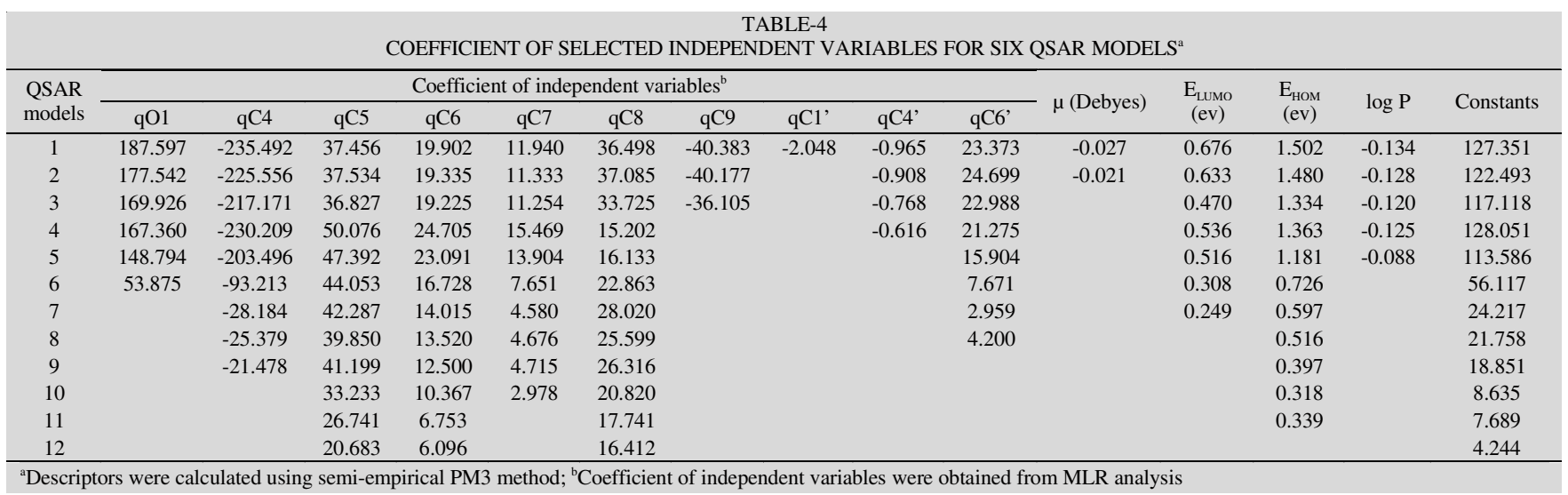


$\left(1 / \log \mathrm{IC}_{50}\right)$ having significance relation at trust level $95 \%$. Meanwhile, the smallest value of SE to indicate that the QSAR model has a very small deviation of data or have highest significance data. The mentioned can be made a guide that the eqn. 1 of QSAR model has more good ability activity of antimalarial flavone derivatives to design. The descriptors selected for modeling antimalarial activity of flavone derivatives are summarized in Tables 3 and 5. The best equation of QSAR model generated for a W2 strain of $P$. falciparum is the eqn. 1 of QSAR model. The best equation of QSAR model (eqn. 1 of QSAR model) is presented in Tables 3 and 4, completely can be written at following:

$$
\begin{aligned}
& 1 / \log \mathrm{IC}_{50}=127.351+187.597(\mathrm{qO} 1)-235.492(\mathrm{qC} 4) \\
& +37.456(\mathrm{qC} 5)+19.902(\mathrm{qC} 6)+11.940(\mathrm{qC} 7)+ \\
& 36.498(\mathrm{qC} 8)-40.383(\mathrm{qC} 9)-2.048\left(\mathrm{qC}^{\prime}\right)-0.965 \\
& \left(\mathrm{qC}^{\prime}\right)+23.373\left(\mathrm{qC}^{\prime}\right)-0.027(\mu)+0.676\left(\mathrm{E}_{\text {LUмо }}\right)+ \\
& 1.502\left(\mathrm{E}_{\text {номо }}\right)-0.134(\log \mathrm{P})
\end{aligned}
$$

$\mathrm{n}=16, \mathrm{r}=0.950, \mathrm{r}^{2}=0.902, \mathrm{SE}=0.18836, \mathrm{~F}_{\text {calculated }} / \mathrm{F}_{\text {table }}=$ 2.686 and PRESS $=0.03600$.

All values of statistical criterion the eqn. 1 of QSAR model has been always superior, when compared with the eleven other equations of QSAR model, unless the value of the SE of eqn. 2 of QSAR model is smaller, when compared with the value of the SE of eqn. 1 of QSAR models (Table-3). The value of $r^{2}$ value has a larger interval than the value of $r$ so small differences are not felt on the $r$ value but can be perceived clearly in $r^{2}$. The $r$ and $r^{2}$ value as statistical parameters display only measures the linearity of the relevant models, but cannot describe the accuracy of the predicted from the equation of QSAR model, so that should be considered by other statistical parameters. The equation of QSAR model obtained is ideal if it has a value of $\mathrm{r}^{2}$ equals and showed a correlation that the independent variables between the dependent variable were perfect and the significance $[13,20]$ if it has a value of $r^{2}$ equal to 0 indicates the electronic structure and properties of molecules (the dependent of variable) between antimalarial activity $\left(\mathrm{IC}_{50}\right)$ have no correlation or insignificant. The statistical parameters commonly using $\mathrm{r}^{2}$ value because having more correctness level than $\mathrm{r}$ value.

Additional the criteria of statistical as support that eqn. 1 of QSAR model as the best equation is a curve graph antimalarial activity value calculation results $\left(1 / \log \mathrm{IC}_{50}\right.$ of predicted) with the antimalarial activity of experimental results $(1 / \log$ $\mathrm{IC}_{50}$ of experiments) in the laboratory (Fig. 1). The result of evaluation antimalarial activity $\left(1 / \log \mathrm{IC}_{50}\right.$ of predicted) and correlation with antimalarial activity $\left(1 / \log \mathrm{IC}_{50}\right.$ of the experiment) for the eqn. 1 of QSAR model by using semi-empiric PM3 method has linearity $\left(r^{2}=0.9004\right)$ and slope value $(0.0812)$ can be seen in Fig. 1 .

According to the value of descriptors seems the most responsible for the pharmacological activity. Important descriptors used in QSAR analysis are very accurate for predicting theoretical antimalarial activities. It can be shown by the $\mathrm{r}^{2}$ value of linear regression analysis between the experimental and the theoretical value of the antimalarial activity. In this research of structure-antimalarial activity relationship reveals that the change of the structure of the substituent group at O1, C4, C5, C6, C7, C8, C9, C1', C4', C6', dipole moment ( $\mu$ ), E $\mathrm{Lumo}_{\text {; }}$ $\mathrm{E}_{\text {номо }}$ and $\log \mathrm{P}$ position commonly results in the change of

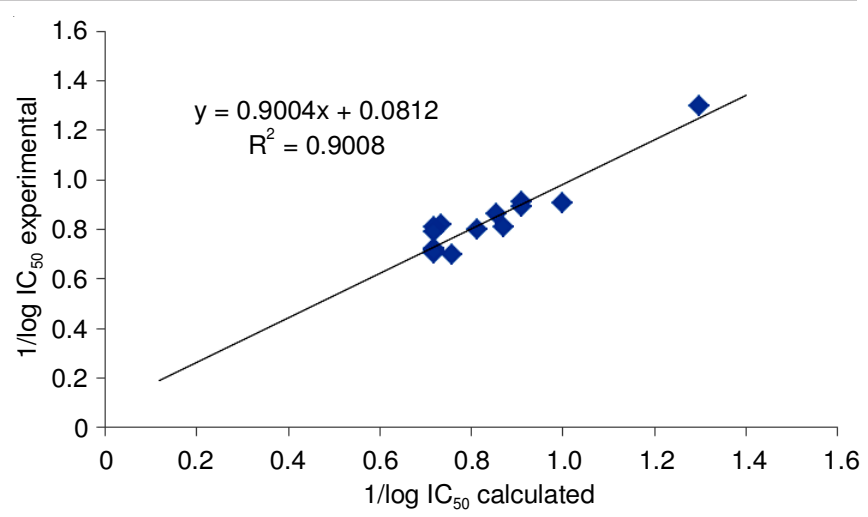

Fig. 1. Linear regression of experimentally antimalarial activity $\left(1 / \log \mathrm{IC}_{50}\right.$ experiment) versus antimalarial activity observed (1/log $\mathrm{IC}_{50}$ calculated) based on QSAR Model 1

its bioactivity. The four substituents (R3, R6, R7 and R4') are functional groups bound to the ring skeleton of the flavone derivative compounds (Table-1) not significant as functional groups affecting the antimalarial activity of flavone derivative molecules, but should be added with substituents R1, R4, R5, R8 and R6' (Table-5) are all important substantially responsible for the enhancement of the value of antimalarial activity theoretically through the design of flavone derivative compounds.

Design of new antimalarial from flavone derivatives: This molecular design is the development of new drug compounds theoretically consists of several stages, namely: (1) the tracking of the flavone derivatives which have been synthesized or isolated but this compound has not been tested in the laboratory antimalarial activity; (2) study retrosynthetic against flavone derivatives that have not yet been isolated or synthesized from natural materials, (3) the optimization of molecules against 16 flavone derivatives using HyperChem ${ }^{\circledR}$ Program Version 8.0 for Windows (Table-1) to calculate a descriptor of each molecule; (4) calculating theoretical values of antimalarial activity ( $\mathrm{IC}_{50}$ of theoretical).

The success of QSAR approach can explain by the insight offered into the structural determination of chemical properties and the possibility to estimate the properties of new chemical compounds without the need to synthesize and test them [21]. In this research, the designed molecule of new antimalarial of flavone derivatives has been done on the basis of the selected the best equation of QSAR model obtained and this equation of QSAR model was then used to predict their actions of antimalarial. In designing of the new flavone derivatives, there functional groups of - $\mathrm{OH}, \mathrm{OCH}_{3},-\mathrm{N}\left(\mathrm{CH}_{3}\right)_{2},-\mathrm{CH}_{3},-\mathrm{Cl},-\mathrm{CF}_{3}$, $-\mathrm{CH}_{2} \mathrm{OH},-\mathrm{CH}\left(\mathrm{NHPh}-4-\mathrm{OCH}_{3}\right)\left(\mathrm{COOC}_{2} \mathrm{H}_{5}\right),-\mathrm{CH}\left(\mathrm{NH}_{2}\right)(\mathrm{Ph}-4-$ $\left.\mathrm{OCH}_{3}\right),-\mathrm{CH}\left(\mathrm{NH}_{2}\right)(\mathrm{Ph}),-\mathrm{CH}\left(\mathrm{NH}_{2}\right)\left(\mathrm{Ph}-4-\mathrm{NO}_{2}\right),-\mathrm{CH}\left(\mathrm{NH}_{2}\right)(\mathrm{Ph}-$ $4-\mathrm{Br}),-\mathrm{CH}\left(\mathrm{NH}_{2}\right)(\mathrm{Ph}-4-\mathrm{Cl}),-\mathrm{CH}\left(\mathrm{NH}_{2}\right)(\mathrm{Ph}-4-\mathrm{F})$ and $-\mathrm{Br}$ substituents were attached to the main skeleton of flavone compounds.

Furthermore, the new flavone compounds were modified so that the higher antimalarial activity of the newly designed molecule compared to that of the previously synthesized compounds was achieved. Table-5 lists the detailed substituent of new antimalarial compounds that have been designed on the basis of the above assumption along with their predicted activity values calculated using the best equation of QSAR model. In this study, the alkyl (R) as substitutions has been replaced using more and less bulky substituent to evaluate the 


\begin{tabular}{|c|c|c|c|c|c|c|c|c|c|c|c|c|}
\hline \multirow{3}{*}{ Compd. } & \multicolumn{10}{|c|}{$\begin{array}{c}\text { TABLE-5 } \\
\text { NEW DESIGNED FLAVONE ANTIMALARIAL COMPOUNDS AND PREDICTED } \\
\log \mathrm{IC}_{50} \text { CALCULATED USING THE BEST QSAR MODEL }\end{array}$} & \multirow{3}{*}{$\begin{array}{c}1 / \log \\
\mathrm{IC}_{50} \\
\text { predicted }\end{array}$} & \multirow{3}{*}{$\begin{array}{c}\mathrm{IC}_{50} \mu \mathrm{M} \\
\text { predicted }\end{array}$} \\
\hline & \multicolumn{10}{|c|}{ Substituents } & & \\
\hline & $\mathrm{R}^{3}$ & $\mathrm{R}^{5}$ & $\mathrm{R}^{6}$ & $\mathrm{R}^{7}$ & $\mathrm{R}^{8}$ & $\mathrm{R}^{2}$ & $\mathrm{R}^{3^{\prime}}$ & $\mathrm{R}^{4}$ & $\mathrm{R}^{5^{\prime}}$ & $\mathrm{R}^{6}$ & & \\
\hline 17 [Ref. 23] & $\mathrm{H}$ & $\mathrm{OH}$ & $\mathrm{H}$ & $\mathrm{OH}$ & $\mathrm{H}$ & $\mathrm{H}$ & $\mathrm{H}$ & $\mathrm{H}$ & $\mathrm{H}$ & $\mathrm{H}$ & 4.210 & 1.728 \\
\hline 18 [Ref. 23] & $\mathrm{H}$ & $\mathrm{OH}$ & $\mathrm{H}$ & $\mathrm{OH}$ & $\mathrm{H}$ & $\mathrm{H}$ & $\mathrm{H}$ & $\mathrm{OH}$ & $\mathrm{H}$ & $\mathrm{H}$ & 6.826 & 1.401 \\
\hline 19 [Ref. 23] & $\mathrm{H}$ & $\mathrm{OH}$ & $\mathrm{H}$ & $\mathrm{OH}$ & $\mathrm{H}$ & $\mathrm{H}$ & $\mathrm{OH}$ & $\mathrm{OH}$ & $\mathrm{H}$ & $\mathrm{H}$ & 6.030 & 1.465 \\
\hline 20 [Ref. 23] & $\mathrm{H}$ & $\mathrm{OH}$ & $\mathrm{H}$ & $\mathrm{OH}$ & $\mathrm{H}$ & $\mathrm{H}$ & $\mathrm{H}$ & $\mathrm{OCH}_{3}$ & $\mathrm{H}$ & $\mathrm{H}$ & 6.805 & 1.403 \\
\hline 21 [Ref. 23] & $\mathrm{OH}$ & $\mathrm{OH}$ & $\mathrm{H}$ & $\mathrm{OH}$ & $\mathrm{H}$ & $\mathrm{H}$ & $\mathrm{H}$ & $\mathrm{OH}$ & $\mathrm{H}$ & $\mathrm{H}$ & 14.526 & 1.172 \\
\hline 22 [Ref. 23] & $\mathrm{OH}$ & $\mathrm{OH}$ & $\mathrm{H}$ & $\mathrm{OH}$ & $\mathrm{H}$ & $\mathrm{H}$ & $\mathrm{OH}$ & $\mathrm{OH}$ & $\mathrm{H}$ & $\mathrm{H}$ & 13.697 & 1.183 \\
\hline 23 [Ref. 23] & $\mathrm{OH}$ & $\mathrm{OH}$ & $\mathrm{H}$ & $\mathrm{OH}$ & $\mathrm{H}$ & $\mathrm{H}$ & $\mathrm{OH}$ & $\mathrm{OH}$ & $\mathrm{OH}$ & $\mathrm{H}$ & 12.973 & 1.194 \\
\hline 24 [Ref. 23] & $\mathrm{OCH}_{3}$ & $\mathrm{OH}$ & $\mathrm{OCH}_{3}$ & $\mathrm{OCH}_{3}$ & $\mathrm{H}$ & $\mathrm{H}$ & $\mathrm{OCH}_{3}$ & $\mathrm{OCH}_{3}$ & $\mathrm{H}$ & $\mathrm{H}$ & 14.684 & 1.170 \\
\hline 25 [Ref. 23] & $\mathrm{OCH}_{3}$ & $\mathrm{OH}$ & $\mathrm{OCH}_{3}$ & $\mathrm{OCH}_{3}$ & $\mathrm{H}$ & $\mathrm{H}$ & $\mathrm{OH}$ & $\mathrm{OCH}_{3}$ & $\mathrm{H}$ & $\mathrm{H}$ & 13.374 & 1.188 \\
\hline 26 [Ref. 23] & $\mathrm{OCH}_{3}$ & $\mathrm{OH}$ & $\mathrm{OCH}_{3}$ & $\mathrm{OCH}_{3}$ & $\mathrm{H}$ & $\mathrm{H}$ & $\mathrm{OCH}_{3}$ & $\mathrm{OH}$ & $\mathrm{H}$ & $\mathrm{H}$ & 14.339 & 1.174 \\
\hline 27 [Ref. 23] & $\mathrm{OCH}_{3}$ & $\mathrm{OH}$ & $\mathrm{H}$ & $\mathrm{OH}$ & $\mathrm{H}$ & $\mathrm{H}$ & $\mathrm{OCH}_{3}$ & $\mathrm{OH}$ & $\mathrm{H}$ & $\mathrm{H}$ & 7.516 & 1.358 \\
\hline 28 [Ref. 23] & $\mathrm{OH}$ & $\mathrm{H}$ & $\mathrm{H}$ & $\mathrm{H}$ & $\mathrm{H}$ & $\mathrm{H}$ & $\mathrm{H}$ & $\mathrm{H}$ & $\mathrm{H}$ & $\mathrm{H}$ & 7.270 & 1.373 \\
\hline 29 [Ref. 24] & $\mathrm{H}$ & $\mathrm{H}$ & $\mathrm{H}$ & $\mathrm{H}$ & $\mathrm{H}$ & $\mathrm{H}$ & $\mathrm{H}$ & $\mathrm{N}\left(\mathrm{CH}_{3}\right)_{2}$ & $\mathrm{H}$ & $\mathrm{H}$ & 8.542 & 1.309 \\
\hline 30 [Ref. 24] & $\mathrm{H}$ & $\mathrm{H}$ & $\mathrm{H}$ & $\mathrm{H}$ & $\mathrm{H}$ & $\mathrm{H}$ & $\mathrm{H}$ & $\mathrm{CH}_{3}$ & $\mathrm{H}$ & $\mathrm{H}$ & 1.945 & 3.268 \\
\hline 31 [Ref. 24] & $\mathrm{H}$ & $\mathrm{H}$ & $\mathrm{H}$ & $\mathrm{H}$ & $\mathrm{H}$ & $\mathrm{H}$ & $\mathrm{H}$ & $\mathrm{Cl}$ & $\mathrm{H}$ & $\mathrm{H}$ & 0.958 & 11.062 \\
\hline 32 [Ref. 24] & $\mathrm{H}$ & $\mathrm{H}$ & $\mathrm{H}$ & $\mathrm{H}$ & $\mathrm{H}$ & $\mathrm{Cl}$ & $\mathrm{H}$ & $\mathrm{Cl}$ & $\mathrm{H}$ & $\mathrm{H}$ & 4.440 & 1.680 \\
\hline 33 [Ref. 24] & $\mathrm{H}$ & $\mathrm{H}$ & $\mathrm{H}$ & $\mathrm{H}$ & $\mathrm{H}$ & $\mathrm{Cl}$ & $\mathrm{Cl}$ & $\mathrm{H}$ & $\mathrm{H}$ & $\mathrm{H}$ & 4.112 & 1.751 \\
\hline 34 [Ref. 24] & $\mathrm{H}$ & $\mathrm{H}$ & $\mathrm{H}$ & $\mathrm{H}$ & $\mathrm{H}$ & $\mathrm{H}$ & $\mathrm{Cl}$ & $\mathrm{Cl}$ & $\mathrm{H}$ & $\mathrm{H}$ & 1.032 & 9.303 \\
\hline 35 [Ref. 24] & $\mathrm{H}$ & $\mathrm{H}$ & $\mathrm{H}$ & $\mathrm{H}$ & $\mathrm{H}$ & $\mathrm{Cl}$ & $\mathrm{H}$ & $\mathrm{H}$ & $\mathrm{H}$ & $\mathrm{Cl}$ & 4.262 & 1.716 \\
\hline 36 [Ref. 24] & $\mathrm{H}$ & $\mathrm{H}$ & $\mathrm{H}$ & $\mathrm{H}$ & $\mathrm{H}$ & $\mathrm{H}$ & $\mathrm{H}$ & $\mathrm{CF}_{3}$ & $\mathrm{H}$ & $\mathrm{H}$ & 0.310 & 1700.429 \\
\hline 37 [Ref. 24] & $\mathrm{H}$ & $\mathrm{H}$ & $\mathrm{H}$ & $\mathrm{OCH}_{3}$ & $\mathrm{H}$ & $\mathrm{H}$ & $\mathrm{H}$ & $\mathrm{CF}_{3}$ & $\mathrm{H}$ & $\mathrm{H}$ & 1.060 & 8.777 \\
\hline 38 [Ref. 24] & $\mathrm{H}$ & $\mathrm{H}$ & $\mathrm{Br}$ & $\mathrm{H}$ & $\mathrm{H}$ & $\mathrm{H}$ & $\mathrm{H}$ & $\mathrm{CF}_{3}$ & $\mathrm{H}$ & $\mathrm{H}$ & 1.305 & 5.835 \\
\hline 39 [Ref. 25] & $\mathrm{H}$ & $\mathrm{H}$ & $\mathrm{H}$ & $\mathrm{OH}$ & $\mathrm{H}$ & $\mathrm{H}$ & $\mathrm{H}$ & $\mathrm{OH}$ & $\mathrm{H}$ & $\mathrm{H}$ & 2.087 & 3.015 \\
\hline 40 [Ref. 25] & $\mathrm{H}$ & $\mathrm{OH}$ & $\mathrm{H}$ & $\mathrm{OH}$ & $\mathrm{H}$ & $\mathrm{H}$ & $\mathrm{H}$ & $\mathrm{OH}$ & $\mathrm{OCH}_{3}$ & $\mathrm{H}$ & 6.522 & 1.423 \\
\hline 41 [Ref. 25] & $\mathrm{OH}$ & $\mathrm{H}$ & $\mathrm{H}$ & $\mathrm{OH}$ & $\mathrm{H}$ & $\mathrm{H}$ & $\mathrm{OH}$ & $\mathrm{OH}$ & $\mathrm{OH}$ & $\mathrm{H}$ & 7.241 & 1.374 \\
\hline 42 [Ref. 25] & $\mathrm{OH}$ & $\mathrm{H}$ & $\mathrm{H}$ & $\mathrm{OH}$ & $\mathrm{H}$ & $\mathrm{H}$ & $\mathrm{OH}$ & $\mathrm{OH}$ & $\mathrm{H}$ & $\mathrm{H}$ & 7.988 & 1.334 \\
\hline 43 [Ref. 25] & $\mathrm{H}$ & $\mathrm{OH}$ & & $\mathrm{OH}$ & $\mathrm{H}$ & $\mathrm{H}$ & $\mathrm{H}$ & $\mathrm{H}$ & $\mathrm{H}$ & $\mathrm{H}$ & 10.365 & 1.249 \\
\hline 44 [Ref. 25] & $\mathrm{H}$ & $\mathrm{OH}$ & & $\mathrm{OH}$ & & $\mathrm{H}$ & $\mathrm{H}$ & $\mathrm{H}$ & $\mathrm{H}$ & $\mathrm{H}$ & 9.325 & 1.280 \\
\hline 45 [Ref. 25] & $\mathrm{H}$ & $\mathrm{OH}$ & & $\mathrm{OH}$ & $\mathrm{H}$ & $\mathrm{H}$ & $\mathrm{H}$ & $\mathrm{H}$ & $\mathrm{H}$ & $\mathrm{H}$ & 10.416 & 1.247 \\
\hline 46 [Ref. 25] & $\mathrm{H}$ & $\mathrm{OH}$ & & $\mathrm{OH}$ & & $\mathrm{H}$ & $\mathrm{H}$ & $\mathrm{H}$ & $\mathrm{H}$ & $\mathrm{H}$ & 9.020 & 1.291 \\
\hline 47 [Ref. 25] & $\mathrm{H}$ & $\mathrm{OH}$ & & $\mathrm{OH}$ & $\mathrm{H}$ & $\mathrm{H}$ & $\mathrm{H}$ & $\mathrm{H}$ & $\mathrm{H}$ & $\mathrm{H}$ & 11.688 & 1.218 \\
\hline 48 [Ref. 25] & $\mathrm{H}$ & $\mathrm{OH}$ & & $\mathrm{OH}$ & $\mathrm{H}$ & $\mathrm{H}$ & $\mathrm{H}$ & $\mathrm{H}$ & $\mathrm{H}$ & $\mathrm{H}$ & 7.080 & 1.384 \\
\hline 49 [Ref. 25] & $\mathrm{H}$ & $\mathrm{OH}$ & & $\mathrm{OH}$ & & $\mathrm{H}$ & $\mathrm{H}$ & $\mathrm{H}$ & $\mathrm{H}$ & $\mathrm{H}$ & 16.394 & 1.151 \\
\hline 50 [Ref. 25] & $\mathrm{H}$ & $\mathrm{OH}$ & & $\mathrm{OH}$ & $\mathrm{H}$ & $\mathrm{H}$ & $\mathrm{H}$ & $\mathrm{H}$ & $\mathrm{H}$ & $\mathrm{H}$ & 7.417 & 1.364 \\
\hline 51 [Ref. 25] & $\mathrm{H}$ & $\mathrm{OH}$ & $\mathrm{CH}_{2} \mathrm{OH}$ & $\mathrm{OH}$ & $\mathrm{H}$ & $\mathrm{H}$ & $\mathrm{H}$ & $\mathrm{H}$ & $\mathrm{H}$ & $\mathrm{H}$ & 6.507 & 1.425 \\
\hline 52 [Ref. 25] & $\mathrm{H}$ & $\mathrm{H}$ & $\mathrm{CH}_{3}$ & $\mathrm{H}$ & $\mathrm{H}$ & $\mathrm{H}$ & $\mathrm{H}$ & $\mathrm{OCH}_{3}$ & $\mathrm{OCH}_{3}$ & $\mathrm{H}$ & 1.189 & 6.935 \\
\hline 53 [Ref. 25] & $\mathrm{H}$ & $\mathrm{H}$ & $\mathrm{Br}$ & $\mathrm{H}$ & $\mathrm{H}$ & $\mathrm{H}$ & $\mathrm{H}$ & $\mathrm{OCH}_{3}$ & $\mathrm{OCH}_{3}$ & $\mathrm{H}$ & 1.631 & 4.104 \\
\hline 54 [Ref. 25] & $\mathrm{H}$ & $\mathrm{H}$ & $\mathrm{H}$ & $\mathrm{OCH}_{3}$ & $\mathrm{H}$ & $\mathrm{H}$ & $\mathrm{H}$ & $\mathrm{OCH}_{3}$ & $\mathrm{OCH}_{3}$ & $\mathrm{H}$ & 1.074 & 8.525 \\
\hline 55 [Ref. 25] & $\mathrm{H}$ & $\mathrm{H}$ & $\mathrm{OCH}_{3}$ & $\mathrm{OCH}_{3}$ & $\mathrm{H}$ & $\mathrm{H}$ & $\mathrm{H}$ & $\mathrm{OCH}_{3}$ & $\mathrm{OCH}_{3}$ & $\mathrm{H}$ & 2.595 & 2.429 \\
\hline
\end{tabular}


effect antimalarial activity. The evaluation was done by comparing the predicted $1 / \log \mathrm{IC}_{50}$ values of the corresponding compounds. The results of the study show that there is a significant difference in the value of predicted of $\log 1 / \mathrm{IC}_{50}$ when $\mathrm{R}$ is varied substitute to keep the different and it has been highest antimalarial activity.

The values of net charge atoms of qO1, qC4, qC5, qC6, qC7, qC8, qC9, QC1', q4', qC6', $\mu, \mathrm{E}_{\mathrm{Lumo}}, \mathrm{E}_{\text {Hомо }}$ and log P for each compound flavone derivatives (results of design) are variables that significantly influence eqn. 1 of QSAR model (Table-3). The descriptors obtained from each of the new compounds, then put in the best equation of QSAR models (eqn. 1 of QSAR model) to obtain the theoretical IC $_{50}$ value of the new compounds of the design results. The flavone derivative compounds having a small $\mathrm{IC}_{50}$ value are an antimalarial compound that has the highest activity. The flavone derivative compounds that have the smallest $\mathrm{IC}_{50}$ value, then the flavone compound has a high probability as antimalarial drugs and may be proposed to be synthesized in the laboratory.

The steps of designed of the quantitative relationship structures and activities conducted in this study were (1) the determination of the series derived flavone be analyzed, along with $\mathrm{IC}_{50}$ values of each compound were generated through laboratory experiments [11], (2) optimization of the structure of the framework basic derivative of flavone most stable and subsequently used as a starting compound in the optimization process, (3) determination of the descriptors (variables), (4) the calculation of descriptors to structural optimization through HyperChem ${ }^{\circledR}$ Program Version 8.0 for Windows, (5) the process of statistical analysis to obtain equation of QSAR models through SPSS ${ }^{\circledR}$ Program Version 16 for Windows, (6) the determination of the best equation of QSAR models, (7) the design of new compounds based on the best QSAR model of flavone derivatives.

The $\mathrm{IC}_{50}$ values of the prediction of new flavone derivatives (results of the design) are presented in Table-5. Table-5 shows that the flavone derivatives (results of the design) are proposed to be synthesized have $\mathrm{IC}_{50}$ values less than the $\mathrm{IC}_{50}$ value of series flavone derivatives presented in Table- 1 . The smallest value of $\mathrm{IC}_{50}$ experiments on a series flavone compounds ever synthesized by Rodrigues et al. [11] was $5.96 \mu \mathrm{M}$. Because the study of molecular design is only theoretical, the authors simply propose new compounds of flavone that have $\mathrm{IC}_{50}$ values below $5.96 \mu \mathrm{M}$ in the hope after tested in the laboratory, the new compound of flavone that has a value lower activity compared with 16 derivatives of flavone that has been synthesized by Rodrigues et al. [11]. There are three factors that are used in the selection of the new flavone derivatives i.e. theoretical activity obtained from the QSAR equation calculation, the possibility in synthesizing the new compound and the ease to get the reactant for synthesis.

The new compound of the flavone derivative (yield design) that have a lower $\mathrm{IC}_{50}$ value of $5.96 \mu \mathrm{M}$ flavone i.e. derivatives 17-30, 32-33, 35, 38-51, 53 and 55 (Table-5), which has a range of $\mathrm{IC}_{50}$ values: $1.151-5.835 \mu \mathrm{M}$. Of course, in the process of synthesis in the laboratory prioritized for compounds having $\mathrm{IC}_{50}$ values less than $2.00 \mu \mathrm{M}$, whereas compounds that have design results in a higher $\mathrm{IC}_{50}$ value of $2.00 \mu \mathrm{M}$ are not recommended to be synthesized or isolated from natural materials.
If the series of flavone derivatives have bound substituents on the ring skeleton of flavone derivatives, then the net charge of atoms to be different from the previous atomic net charge. The different substituents on the main skeleton of flavone derivatives can lead to differences in the atomic charge and the nature of the compound and may lead to differences in drug activity of the flavone compounds [16,22]. Table- 5 shows that the flavone derivatives have a different structure, which can be produced different antimalarial activity. In addition to the above-mentioned symptoms, it is also found other symptoms that if Table-5 is compared with Table-1, it is seen that the position and type of substituents attached to the skeleton of the ring of the flavone derivatives greatly affect the magnitude of the net charge value of the atoms. Based on the above, it can be concluded that the different structures have electronic properties (net charge of atoms and other descriptors) are different. If the flavone derivative compounds having different electronic properties, then the flavone derivatives having different antimalarial activity. In addition to the above, the position of functional groups attached to one ring of flavone compounds can also affect the difference in value and the value $\mathrm{E}_{\text {номо- }}$ $\mathrm{E}_{\mathrm{LUmo}}$ of a series of flavone derivatives. Different substituent or functional group attached to a flavone compound can specify different values and value of $\mathrm{E}_{\mathrm{HOMO}}-\mathrm{E}_{\mathrm{LUMO}}$ against the structure of flavone derivative compounds is different (Fig. 2).

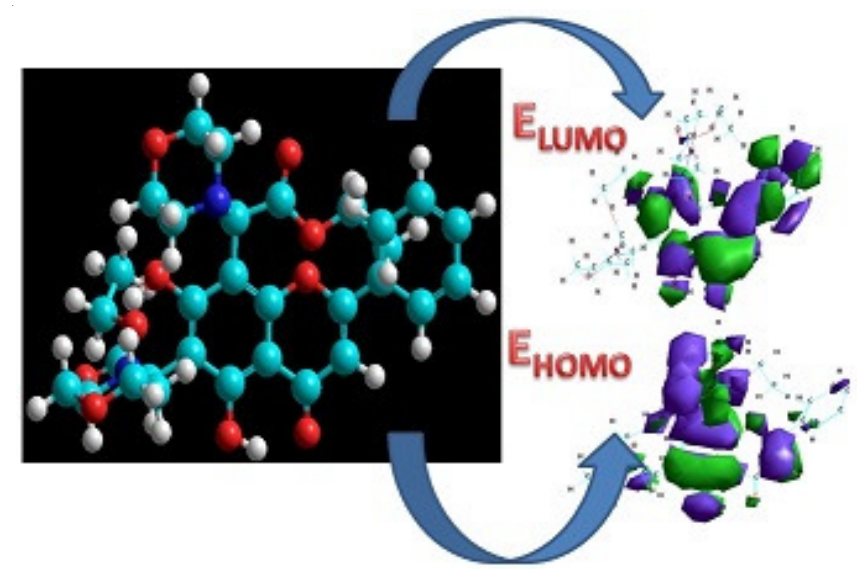

Fig. 2. Difference of $\mathrm{E}_{\mathrm{LUMO}}$ and $\mathrm{E}_{\mathrm{HOMO}}$ against different molecular structures of flavone derivatives

\section{Conclusion}

Based on the results and discussion of this study, it can be concluded that the eqn. 1 of QSAR model as the best equation of QSAR model to determine the relationship between antimalarial activity with latent variables against the 16 flavone derivatives is $1 / \log \mathrm{IC}_{50}=127.351+187.597(\mathrm{qO} 1)-235.492$ $(\mathrm{qC} 4)+37.456(\mathrm{qC} 5)+19.902(\mathrm{qC} 6)+11.940(\mathrm{qC} 7)+36.498$ $(\mathrm{qC} 8)-40.383(\mathrm{qC} 9)-2.048\left(\mathrm{qC} 11^{\prime}\right)-0.965\left(\mathrm{qC} 4{ }^{\prime}\right)+23.373$ $\left(\mathrm{qC} 6{ }^{\prime}\right)-0.027(\mu)+0.676\left(\mathrm{E}_{\mathrm{LUMO}}\right)+1.502\left(\mathrm{E}_{\text {Hомо }}\right)-0.134(\log$ $\mathrm{P}) ; \mathrm{n}=16, \mathrm{r}=0.950, \mathrm{r}^{2}=0.902, \mathrm{SE}=0.18836, \mathrm{~F}_{\text {calculated }} / \mathrm{F}_{\text {table }}=$ 2.686 and PRESS $=0.03600$. The analysis of MLR was calculated by using the backward method. Based on the best equation of QSAR model has been designed by 51 of flavone derivative compounds having a functional group attached to R3, R5, R6, R7, R8, R2', R3', R4', R5' and R6'. Based on the 
results of the design, It can be recommended that as many as 28 of flavone derivative compounds be synthesized or isolated in a laboratory that was derived from flavone compounds are: $17-29,32-33,35$ and 40-51 which have a range of $\mathrm{IC}_{50}$ values 1.151-1.751 $\mu \mathrm{M}$. In this research, it has been found that the descriptors qO1, qC4, qC5, qC6, qC7, qC8, qC9, qC1', q4', qC6', $\mu, \mathrm{E}_{\mathrm{Lumo}}, \mathrm{E}_{\text {Hомо }}$ and $\log \mathrm{P}$ as hypothetical active in the molecular region of flavone derivatives, seems to be the most responsible for the pharmacological activity of flavone derivative compounds.

\section{REFERENCES}

1. WHO, World Malaria Report, World Health Organization, Geneva (2016)

2. G. Vogel, Science, 329, 618 (2010); https://doi.org/10.1126/science.329.5992.618.

3. A. Widyawaruyanti, N.C. Zaini and Syafruddin, J. Bina Praja (Indonesia), 13, 67 (2011).

4. J. Bero, M. Frédérich and J. Quetin-Leclercq, J. Pharm. Pharmacol., 61, 1401 (2009); https://doi.org/10.1211/jpp.61.11.0001

5. J.E. Hyde, Parasitol., 21, 494 (2005); https://doi.org/10.1016/j.pt.2005.08.020.

6. A.M. Dondorp, F. Nosten, P. Yi, D. Das, A.P. Phyo, J. Tarning, K.M. Lwin, F. Ariey, W. Hanpithakpong, S.J. Lee, P. Ringwald, K. Silamut, M. Imwong, K. Chotivanich, P. Lim, T. Herdman, S.S. An, P. Singhasivanon, S. Yeung, N.P.J. Day, N. Lindegardh, D. Socheat and N.J. White, N. Engl. J. Med., 361, 455 (2009) https://doi.org/10.1056/NEJMoa0808859.

7. M.A. Elfawal, M.J. Towler, N.G. Reich, P.J. Weathers and S.M. Rich, Proc. Natl. Acad. Sci. USA, 112, 821 (2015); https://doi.org/10.1073/pnas.1413127112.

8. A.J. Humberstone, C.J. Porter, G.A. Edwards and W.N. Charman, J. Pharm. Sci., 87, 936 (1998); https://doi.org/10.1021/js9704846.

9. Mustofa, A.D. Yappi, A. Valentin and I. Tahir, J. Med. Sci., 35, 67 (2003).

10. F. Monbrison, M. Maitrejean, C. Latour, F. Bugnazet, F. Peyron, D. Barron and S. Picot, Acta Trop., 97, 102 (2006); https://doi.org/10.1016/j.actatropica.2005.09.004
11. T. Rodrigues, A.S. Ressurreicao, F.P. da Cruz, I.S. Albuquerque, J. Gut, M.P. Carrasco, D. Gonçalves, R.C. Guedes, D.J.V.A. dos Santos, M.M. Mota, P.J. Rosenthal, R. Moreira, M. Prudêncio and F. Lopes, Eur. J. Med. Chem., 69, 872 (2013); https://doi.org/10.1016/j.ejmech.2013.09.008.

12. E. Vicente, P.R. Duchowicz, E.A. Castro and A. Monge, J. Mol. Graph. Model., 28, 28 (2009); https://doi.org/10.1016/j.jmgm.2009.03.004.

13. M.J.S. Dewar, E.G. Zoebisch, E.F. Healy and J.J.P. Stewart, J. Am. Chem. Soc., 107, 3902 (1985); https://doi.org/10.1021/ja00299a024..

14. P.R. Duchowicz, M. Fernández, J. Caballero, E.A. Castro and F.M. Fernández, Bioorg. Med. Chem., 14, 5876 (2006); https://doi.org/10.1016/j.bmc.2006.05.027.

15. P.R. Duchowicz, M.G. Vitale, E.A. Castro, M. Fernández and J. Caballero, Bioorg. Med. Chem., 15, 2680 (2007); https://doi.org/10.1016/j.bmc. 2007.01.039.

16. M. Goodarzi, P.R. Duchowicz, C.H. Wu, F.M. Fernández and E.A. Castro, J. Chem. Inf. Model., 49, 1475 (2009); https://doi.org/10.1021/ci900075f.

17. P. Iswanto, M. Chasani, Harjono, I. Tahir, M. Hanafi and E. Vaulina YD, Indones. J. Chem., 11, 31 (2011).

18. D. Munirajasekhar, M. Himaja and V.M. Sunil, Int. Res. J. Pharm., 2, 114 (2011).

19. M. Kumar, B. Narasimhan, P. Kumar, K. Ramasamy, V. Mani, R.K. Mishra and A.B.A. Majeed, Arab. J. Chem., 7, 436 (2014); https://doi.org/10.1016/j.arabjc.2013.03.002.

20. L.F. Motta, A.C. Gaudio and Y. Takahata, Internet Electron. J. Mol., 5, 555 (2006)

21. M. Kumar, K. Ramasamy, V. Mani, R.K. Mishra, A.B.A. Majeed, E.D. Clercq and B. Narasimhan, Arab. J. Chem., 7, 396 (2014); https://doi.org/10.1016/j.arabjc.2012.12.005.

22. P.R. Duchowicz, A. Talevi, L.E. Bruno-Blanch and E.A. Castro, Bioorg. Med. Chem., 16, 7944 (2008); https://doi.org/10.1016/j.bmc.2008.07.067.

23. T.P.T. Cushnie and A.J. Lamb, Int. J. Antimicrob. Agents, 26, 343 (2005); https://doi.org/10.1016/j.ijantimicag.2005.09.002.

24. H. Mohammed, Doctoral Thesis, Universität des Saarlandes, Saarbrücken, Germany (2009).

25. M. Shoaib, S.W.A. Shah, N. Ali, I. Shah, M.N. Umar and M.N. Shafiullah, Bulg. Chem. Commun., 48, 414 (2016). 